Appleton, J, Powell, C and Coombes, L

Children's missed healthcare appointments: professional and organisational responses

Appleton, J, Powell, C and Coombes, L (2016) Children's missed healthcare appointments: professional and organisational responses. Archives of Disease in Childhood, 101 (9). pp. 814-818.

doi: 10.1136/archdischild-2015-309621

This version is available: https://radar.brookes.ac.uk/radar/items/ffe5e9aa-eeab-4202-aea3-7cd599e06730/1/

Available on RADAR: October 2016

Copyright (C) and Moral Rights are retained by the author(s) and/ or other copyright owners. A copy can be downloaded for personal non-commercial research or study, without prior permission or charge. This item cannot be reproduced or quoted extensively from without first obtaining permission in writing from the copyright holder(s). The content must not be changed in any way or sold commercially in any format or medium without the formal permission of the copyright holders.

This document is the postprint version of the journal article. Some differences between the published version and this version may remain and you are advised to consult the published version if you wish to cite from it. 
Professor Jane Appleton BA(Hons), RGN, RHV, MSc, PhD, PGCEA.

Professor of Primary and Community Care

Faculty of Health \& Life Sciences

Oxford Brookes University

Jack Straw's lane

Marston

Oxford,

England OX3 OFL

Tel. 01865482606

Fax. 01865482775

Email: jvappleton@brookes.ac.uk

Dr. Catherine Powell PhD BNSc. (Hons) RGN RSCN RHV

Safeguarding Children Consultant \& Visiting Academic

University of Southampton

Highfield

Southampton,

England SO17 1BJ

Lindsey Coombes RMN RGN BA (Hons) PGCEA MA

Principal Lecturer/Research Fellow

Faculty of Health \& Life Sciences

Oxford Brookes University

Jack Straw's lane

Marston

Oxford OX3 OFL

Keywords: Child Abuse, Children's Rights, Missed Appointments, Was Not Brought, Qualitative Research

Word count: 2649 words 


\section{Children's missed healthcare appointments: professional and organisational responses}

\section{ABSTRACT}

Aim: This NSPCC funded UK study sought to examine organisational and professional responses to children's missed health care appointments.

Design/Methods: The study comprised two parts: Phase one was a web-based scoping and systematic analysis of UK NHS health care organisations' internal policies on missed appointments. Phase two involved a case study of how missed appointments were managed within one hospital Trust, including interviews with hospital-based staff, review of organisational data and examination of policies and 'systems' in place.

Results: Policies accessed were of variable quality when benchmarked against a predetermined set of evidence-based standards. Additional material (e.g. Board minutes) gleaned through the searches found an apparent disconnect between nationally determined safeguarding requirements and strategies to reduce the cost-pressures arising from missed appointments. Findings from the case study included the continuing use of the adult-centric term 'did not attend' (DNA), the challenges that may be inherent in attending appointments (with concomitant sympathy for parents) and a need to further explore general practitioner responses to DNA notifications, particularly given the acknowledged association between missed appointments and child maltreatment.

Conclusions: The web-based scoping exercise yielded a small number of organisational policies. These were of variable quality when rated against pre-determined standards. Other material gathered through the search strategy found evidence that 'missed appointment' strategies aimed at reducing costs did not always acknowledge the discrete needs of children. The casestudy findings contribute to an understanding of the complexities and challenges of responding to a missed appointment, and the importance of taking a child-centred approach. 


\section{INTRODUCTION}

Children have a fundamental right to access the healthcare that they need in order to achieve maximum health and wellbeing. Parents have the primary responsibility to ensure their child's health needs are met and this includes ensuring they access healthcare appointments. A failure to ensure healthcare access is linked to poor outcomes and recognised as a child protection matter within statutory definitions of neglect. ${ }^{1}$ It is also a known feature in the history of children who have suffered serious maltreatment. ${ }^{2}$ For this reason children's health policy has promoted the importance of following up children who fail to attend for healthcare.

The Care Quality Commission (CQC) review of the safeguarding children arrangements in healthcare settings in England, found that 32\% of acute Trusts and 49\% of Primary Care Trusts did not have a policy to support the follow-up of children's missed appointments. ${ }^{3}$ Healthcare organisations may respond as they would to a competent adult i.e. to record DNA 'Did Not Attend' in the case-notes, send a further appointment and, if that too is missed, discharge from follow-up, with (usually) a letter to the general practitioner (GP). Powell and Appleton $^{4(p .183)}$ suggested a "re-conceptualisation of DNA to 'Was Not Brought' (WNB)" to encourage health professionals to take a proactive and child centred stance in safeguarding the well-being of children who miss appointments. Others ${ }^{5,6,7}$ have additionally identified a need to better understand the relationship between non-attendance and risk of harm and to promote good practice in following up children who are not brought to their healthcare appointments.

This study aimed to examine factors (at both the individual and systems level) that contribute to health care professionals' responses to children's missed health care appointments and begin to inform recommendations for best practice.

\section{METHODS}

The study began in 2013 and involved two phases. The first was a web-based scoping review of UK NHS provider organisations' compliance with policies for managing children's missed appointments. This was undertaken during March/April 2014. The second was a case study to ascertain how missed appointments are managed in one NHS Hospital Trust. 


\section{Phase One: Scoping Review}

The scoping review scrutinised 210 NHS and independent provider websites across the UK for publicly available guidance on the management of children's missed healthcare appointments. Of these, 206 had a 'search' facility and the following search terms were applied: safeguarding children; child protection; DNA; Did not attend; WNB; Was not Brought; No access visit; Missed appointment(s); Failure to attend appointment(s). For England this included accessing and reviewing the public 'declaration' of attainment of CQC safeguarding standards. ${ }^{3}$ A Google search, applying the same search terms was also undertaken.

Where policies were accessed, they were systematically analysed and rated according to a framework based on a set of evidence informed pre-determined standards devised by the authors to elicit best practice (Table 1 ). The standards were devised to reflect legislation, policy and good practice in safeguarding and clinical governance. Each standard was rated with a score of either: 0 - Not met, 1 - Partially met or 2 - Fully met (Table 3).

\section{Phase Two: Case Study}

Case study research excels at bringing understanding of a complex system. ${ }^{8}$ Stake described case study methodology as a strategy of inquiry in which the researcher explores in-depth a program, event, activity, process or one or more individuals. ${ }^{8}$ Cases are bounded by time and activity, and researchers collect detailed information using a variety of data collection procedures over a sustained period of time. For this case study we explored how one NHS Provider Trust managed children's missed healthcare appointments. Data were collected through: (1) document analysis (i.e. review of the organisation's missed appointment policies and protocols), (2) semistructured audiotape recorded interviews with 13 hospital based staff lasting 30-40 minutes and (3) review of organisational data and examination of the 'systems' in place.

A purposive sampling strategy was adopted to recruit a range of staff through the Trust's Safeguarding Children Strategy Group. Semi-structured interviews using a topic guide were conducted and audio-recorded where participants agreed. Topics included: reasons for DNA/WNB, how missed appointments are followed up, decisions about this, knowledge of policies and procedures and children on child protection plans. Interviews were transcribed verbatim, data were organised using NVivo and analysed thematically. ${ }^{9}$ Codes were developed into categories corresponding to key aspects of the Trust's 'missed appointment protocol' protocol and discussed amongst the research team. 
Our case study analysed the Trust's missed appointment protocols and reviewed organisational data on children's missed appointments (outpatient DNAs) this latter data is not reported to preserve site anonymity). We also explored, through discussions with a senior safeguarding lead, the feasibility of 'tracking' DNA cases through the hospital system to map follow-up action. While access approvals were negotiated, ethical approval was sought concurrently. The study was approved by the National Research Ethics Service in October 2013 (reference 13/NE/0135).

\section{RESULTS}

\section{Phase One: Scoping review}

Using web-based NHS service directories ${ }^{10-13}$ we accessed health provider web-sites for each of the four countries of the UK. The searches led to a number of publically-available safeguarding children/missed appointment policies; 'declarations of compliance' against the CQC safeguarding standards ${ }^{3}$ (for England) and additional material relating to strategies to reduce 'DNA' rates generally (e.g. Board minutes). The search findings are summarised in Table 2.

The web-based scoping found 24 'children's missed appointments' policies that could be accessed via public internet sites. Policies were scrutinised and rated against pre-determined standards (Table 1). They were of variable quality and none was found to meet the expected standards in full. However, we rated one policy as ten and five policies as 11 (out of a potential score of 12). The mean was 7.2 (range 3-11). The additional material relating to missed appointments uncovered by the searches was primarily about managing 'the system' and introducing penalties for non-attendees, with limited evidence of children's discrete needs.

\section{Phase Two: NHS Provider Case Study}

The findings presented here draw chiefly on the analysis of the data from the semi-structured interviews with hospital-based staff. Thirteen participants were interviewed (11 face-to-face and 2 by telephone). See Table 4 for the staff involved. Table 5 illustrates the five key themes that arose from the coding and categorisation of the interview transcripts.

\section{Missed Appointments - policy and terminology}

The case study interviews provided an understanding of the perspective of hospital staff (clinical and administrative) on 'DNA'. This term was used to refer either to the young person who has failed to attend, or the parent/carer who has failed to bring their child to an appointment. In the emergency department, cases were referred to as 'Did not Wait' (to be seen). The language used is important as it provides insights into how staff working in the NHS conceive the 
phenomena. Most interviewees used the term 'DNA' rather than 'WNB'. Most were aware of the Trust policy (which refers to both Did Not Attend (DNA) and Denied Access Visits); some thought the policy was important because it emphasised clinical accountability about whether 'another appointment is necessary or not'. Some participants commented that it was not easy to find the policy on the Trust's intranet, whilst others suggested that awareness of it should be raised during safeguarding training.

\section{Response to the missed appointment}

The case study participants took a sympathetic view to the challenges of attending an outpatient appointment, whilst still recognising the link with safeguarding. Where missed appointments raise concerns about potential safeguarding issues, referral to children's social care was noted as a response. However, variation in response was also apparent: sometimes repeated missed appointments were necessary to trigger a reaction by services; sometimes a single missed appointment was sufficient to evoke a response. One practitioner commented:

'she missed [the appointment]... our normal approach for DNA's would be that for anyone who DNA's we would automatically write a letter saying 'we're very sorry you missed your appointment, if you'd like another one please telephone the secretary'. In these circumstances, where this child was clearly at risk...I contacted mum directly via the telephone... she has been an intermittent DNAer in the time that we've worked together and...it's been apparent to me that she tends to DNA if she hasn't been able to follow through on something that we've discussed in a previous session, and so we kind of have a system whereby I do a little bit more active chasing and then she reengages'

In this example prior knowledge of the family aided decision making. Where there was no/little information about a child or family, this was reported to create difficulties in making a decision based on one missed appointment.

There was recognition that DNA cases are often quite different. The importance of considering the consequences for the child was raised by some respondents, including:

- What are the consequences of these missed appointments for the child/young person?

- What is known already about the family?

- Why have there been previous missed appointments? 
- Has the clinician spoken directly to the parent about what's happening?

- Does the parent understand the need to get the child to the appointment?

The most common approach to missed appointments was 'to refer back to GP' (and sometimes to the health visitor or school nurse).

Several participants identified the difficulty of assessing risk. An initial missed appointment may be considered low/medium risk by a practitioner, but this adds to the potential difficulty of picking up a pattern of missed appointments across primary and secondary services. Additionally, despite recommendations dating back to the Victoria Climbié Inquiry ${ }^{14}$ it became apparent that children may have several sets of hospital case-notes as a result of being seen by different specialities.

\section{Reasons for non-attendance}

Respondents described a range of factors which may result in children missing their hospital appointments, including financial constraints, child care difficulties and problems to do with the hospital system itself, such as lack of parking and limited weekend/evening clinics. The time commitment required to attend hospital appointments was also identified as a factor. This was exacerbated when parents bring children for frequent appointments, when they had to take annual leave if employers were inflexible and when certain clinics were known to 'always run late', raising issues about appointment scheduling. There was also a view that the hospital appointment system may intensify difficulties for families with chaotic lifestyles i.e. the practice in some departments of giving a child/family several appointments in advance which some parents find difficult to manage.

\section{Child-focussed?}

Placing the child at the centre of care means professionals and organisations adopting a stance that recognises and responds to the child's best interests. We noted some participants reported attendances at children's appointments as if the parent was the primary client; for example 'when she comes' (the child was male). Another commented:

'And the first couple of appointments they attended very well, I think I engaged with mum very well and she was clear that she wanted to do some work on changing his 
weight and obviously Social Care were pressing me to ensure she attended all appointments.'

The literature recognises that the most successful workers in safeguarding adopt a flexible and honest approach with families, also conveying sensitivity to their problems. ${ }^{15,16}$ However, sympathy for the parent, can prevent professionals from 'seeing the child' and serving their best interests ${ }^{14}$.

\section{General Practice}

The most common approach to non-attendance was to notify the GP and/or primary care team. However, the degree to which a busy General Practice is able to provide the monitoring, assessment and referral (back into the 'system'), or take a lead in taking forward a missed appointment (or several) as a safeguarding concern was raised. One practitioner commented:

'...community health professionals have got huge workloads and they don't do as much as they used to do, sadly, ...so really you can't rely on that safety net because they may not see the child very often at all and that's quite worrying really because the universal services I think have taken a knock and unless it's a child on a Child Protection Plan or a child with a particular kind of alert flag on it, they could get missed...'

Such concerns have been previously noted in the literature. ${ }^{17}$

\section{Discussion}

Few studies have examined children's missed health care appointments, and none have rated the quality of policies in use, as this study has done. However we were limited to an examination of those policies we could obtain. Our concerns at the outset, that the majority of providers would place their policies on 'intranets' appeared to be the case. This supports the findings of a recent mapping of DNA guidelines in English NHS organisations which found that fewer than $8 \%$ had publicly accessible policies. ${ }^{6}$ We suggest that placing internal policies on the internet and intranet helps to promote and share good practice, reduces wastage from time spent 're-inventing the wheel' and helps to inform openness and transparency in service delivery. 
In terms of rating the policies, each standard was scored the same and there was no weighting, yet some standards might be considered more vital than others. If only the first 5 standards were used, then $6 / 24$ policies would have scored $10 / 10$, which shows good policies do already exist in some Trusts. The finding that policies were rated poorly on the presence of an 'auditable quality standard' (no policy scored 2 points for Standard 6) is important, as audit is an essential component of quality improvement activity.

Older children should be involved in decisions about their care ${ }^{18}$ and this includes actions that may be taken if they fail to attend. It was pleasing to find policies generally recognised that 'childhood' extends to 18 years. However, 'paediatrics' does not necessarily cover the care of 16 and 17 year olds and a study limitation is that we have not been able to ascertain the degree to which this age group's particular needs are recognised.

Additionally, whilst raising safeguarding concerns may be in the child's best interests, we were concerned about the involvement of families in being made aware of the decision to refer to children's social care (in line with good practice and statutory guidance). This was not always articulated in the guidelines reviewed.

\section{Implications}

Missed health care appointments continue to have a major impact on the health economy. We found evidence that provider organisations are continuing to develop strategies to reduce nonattendance, but that that these do not always feature the needs of children. This led to a question about whether there was a tension arising from the pressures to improve the management of schedules to reduce costs from missed appointments across the whole age spectrum (a largely administrative undertaking) with a concomitant failure to recognise the differing needs of children and young people. What was missing from our findings was an assurance that 'DNA Policies' concerning children were subject to audit and evaluation. We recommend that readers may wish to review the quality of their own organisational policies against the quality standards described in Table 1.

Both phases of the study found that NHS professionals continue to use and favour the term 'DNA'. This is not to say that they are not considering the wider aspects of children's missed appointments; including the challenges that may be inherent in attending hospital appointments. However, the continued occurrence of missed appointments in serious cases of child maltreatment indicates that awareness of their significance is still not sufficient. Re- 
conceptualising DNA to WNB may help to promote awareness of the connections of missed appointments with wider safeguarding issues.

This study has helped to inform our understanding of the complexities and challenges of responding to children's DNA in the acute hospital setting; but there remain gaps in knowledge of 'what is happening' that can only be addressed through a more extensive study that involves children and their families. There also needs to be an understanding of the degree to which general practice staff are aware of the importance of children's missed healthcare appointments, or indeed, whether or not they have been alerted to, or consulted on policies that directly involve them.

\section{Acknowledgements}

This study has been made possible by a grant from the National Society for the Prevention of Cruelty to Children (NSPCC).

We would like to express our sincere appreciation to all the study participants who contributed their valuable insights and perspectives to this study. We would also like to thank the hospital Trust that supported the study.

\section{What is already known on this topic:}

Missed health care appointments have a major impact on the health economy; with organisations required to put strategies in place to manage and reduce 'waste'.

A failure to ensure access to health care is linked to poor outcomes and recognised as a child protection matter within statutory definitions of neglect.

Nationally determined child health and safeguarding policies promote children's fundamental right to health care and the importance of following up children who fail to attend.

\section{What this study adds:}

Six quality standards for organisations to review their own DNA/WNB policies against;

Insights into the systems, complexities and challenges of responding to children's missed appointments in the acute hospital setting from the perspective of staff working in an NHS Provider Trust.

A series of questions are raised to enable NHS staff to consider the consequences for the child of missed appointments. 


\section{References}

(1) HM Government Working Together to Safeguard Children: a guide to inter-agency working to safeguard and promote the welfare of children. London: Department for Education, 2015. Available from URL: www.gov.uk/government/publications/working-together-tosafeguard-children--2 (accessed 3 June 2015)

(2) Brandon M, Sidebotham P, Bailey S, Belderson P, Hawley C, Ellis C, Megson M. New Learning from Serious Case Reviews. London: Department for Education, 2012.

(3) Care Quality Commission (CQC). Safeguarding Children: a review of arrangements in the NHS for safeguarding children. London: Care Quality Commission, 2009.

(4) Powell C, Appleton J.V. Children and young people's missed healthcare appointments: reconceptualising 'Did Not Attend' to 'Was Not Brought' - a review of the evidence for practice Journal of Research in Nursing. 2012; 17, 181-192

(5) Arai L, Stapley S, Roberts H. 'Did not attends' in children 0-10: a scoping review Child: Care, Health, and Dev. 2014; 40, 6, 797-805 doi:10.1111/cch.12111

(6) Arai L, Stephenson T, Roberts $H$. The unseen child and safeguarding: 'Did not attend' guidelines in the NHS. Arch Dis Child. 2015;100:517-520

(7) Roe MFE, Appleton JV \& Powell C. Why was this child not brought? Arch Dis Child 2015;100:6 511-512

(8) Stake, R.E. The Art of Case Study Research. London: Sage Publications, 1995.

(9) Braun V, Clarke, V. Using thematic analysis in psychology. Qualitative Research in Psychology, 2006; 3, 2, 77-101.

(10) http://www.nhs.uk/servicedirectories/pages/acutetrustlisting.aspx

(11) http://www.nhs.uk/servicedirectories/pages/acutetrustlisting.aspx

(12) https://www.wales.nhs.uk/ourservices/directory/LocalHealthBoards

(13) http://www.gov.scot/Topics/Health/NHS-Workforce/NHS-Boards

(14) Laming, Lord. The Victoria Climbié Inquiry: Report of an Inquiry by Lord Laming CM 5730. London: The Stationery Office, 2003.

(15) Saint-Jacques M.C, Drapeau S, Lessard G, Beaudoin A. Parent involvement practices in child protection: A matter of know-how and attitude. Child and Adolescent Social Work Journal. 2006; 23, 2, 196-215.

(16) Holland, S. The assessment relationship: interactions between social workers and parents in child protection assessments British Journal of Social Work 2000; 30, 149-163.

(17) Appleton J.V. Delivering safeguarding children services in primary care: responding to national child protection policy. Primary Healthcare Research \& Development 2012; 13, 6071.

(18) Department of Health (DH). Seeking Consent: working with children. London: Department of Health, 2001. 


\section{Table 1 Standards for Rating Policies}

1. The policy/procedure provides a definition of childhood that recognises that childhood goes up to 18 years of age (as per legislation)

2. The policy/procedure reflects the UN Convention/Children Act 1989 and the duty to meet the welfare and protection needs of CYP, including access to healthcare

3. The policy/procedure provides a statutory definition of neglect that includes the failure to ensure access to healthcare (as per Working Together) ${ }^{1}$

4. The policy/procedure makes reference to the importance of following up children who miss healthcare appointments (rationale - evidence - research SCRs)

5. The policy/procedure provides clear guidance on the action that should be taken to follow up children who miss healthcare appointments (action staff expected to take)

6. The policy/procedure provides an auditable quality standard in relation to following up children who miss healthcare appointments. (ref to audit in practice) 
Table 2 Scoping Review Results: Children's Missed Appointment Policies and Guidance following UK wide search.

\begin{tabular}{|c|c|c|c|c|c|}
\hline & $\begin{array}{c}\text { Total } \\
\text { number of } \\
\text { web-sites } \\
\text { visited }\end{array}$ & $\begin{array}{c}\text { Publically } \\
\text { available } \\
\text { policy }\end{array}$ & $\begin{array}{c}\text { Publically } \\
\text { available } \\
\text { guidance }\end{array}$ & $\begin{array}{l}\text { Declaration } \\
\text { of } \\
\text { compliance } \\
\text { (CQC) }\end{array}$ & $\begin{array}{c}\text { Declaration of } \\
\text { compliance references } \\
\text { policy for children's } \\
\text { missed appointments }\end{array}$ \\
\hline England & $\begin{array}{c}180 / 185 \\
\text { NHS Trusts/ } \\
\text { Foundation } \\
\text { Trusts }\end{array}$ & 19 & 0 & $144 / 180$ & $125 / 144$ \\
\hline Wales & $\begin{array}{l}7 \text { health } \\
\text { boards }\end{array}$ & 1 & 1 & & \\
\hline Scotland & $\begin{array}{l}\text { One main } \\
\text { website for } \\
14 \text { health } \\
\text { boards }\end{array}$ & 0 & 1 & & \\
\hline $\begin{array}{l}\text { Northern } \\
\text { Ireland }\end{array}$ & $\begin{array}{l}\text { One main } \\
\text { website } \\
\text { linked to } \\
5 \text { regional } \\
\text { websites }\end{array}$ & 1 & 1 & & \\
\hline $\begin{array}{l}\text { Independent } \\
\text { providers }\end{array}$ & 3 & 0 & 0 & & \\
\hline
\end{tabular}

CQC not applicable

$=$ CQC not applicable

\footnotetext{
${ }^{1}$ Care UK; Virgin Healthcare; BUPA.
} 
Table 3. Rating of policies (for full definitions of Standards see Table 1)

\begin{tabular}{|c|c|c|c|c|c|c|c|}
\hline Trust (anon) & $\begin{array}{l}\text { Standard 1: } \\
\text { Definition } \\
\text { of } \\
\text { Childhood }\end{array}$ & $\begin{array}{l}\text { Standard 2: } \\
\text { Reflects UN } \\
\text { Convention } \\
\text { /Children } \\
\text { Act } 1989\end{array}$ & $\begin{array}{l}\text { Standard 3: } \\
\text { Provides } \\
\text { statutory } \\
\text { definition of } \\
\text { neglect }\end{array}$ & $\begin{array}{l}\text { Standard 4: } \\
\text { Ref to } \\
\text { follow-up of } \\
\text { missed } \\
\text { appointmen } \\
\text { ts }\end{array}$ & $\begin{array}{l}\text { Standard } \\
\text { 5: } \\
\text { Provides } \\
\text { guidance } \\
\text { on action } \\
\text { to be } \\
\text { taken }\end{array}$ & $\begin{array}{l}\text { Standard 6: } \\
\text { Policy has } \\
\text { an } \\
\text { auditable } \\
\text { standard. }\end{array}$ & Total \\
\hline $\mathbf{a}$ & 2 & 0 & 2 & 0 & 0 & 0 & 4 \\
\hline b & 0 & 0 & 0 & 1 & 2 & 1 & 4 \\
\hline c & 2 & 2 & 2 & 2 & 2 & 1 & 11 \\
\hline d & 0 & 1 & 0 & 2 & 2 & 1 & 6 \\
\hline e & 2 & 2 & 2 & 2 & 2 & 1 & 11 \\
\hline f & 0 & 0 & 1 & 1 & 0 & 1 & 3 \\
\hline g & 2 & 1 & 2 & 1 & 1 & 0 & 7 \\
\hline h & 2 & 2 & 2 & 2 & 2 & 0 & 10 \\
\hline i & 1 & 1 & 0 & 1 & 2 & 0 & 5 \\
\hline $\mathbf{j}$ & 2 & 1 & 2 & 1 & 1 & 0 & 7 \\
\hline k & 2 & 2 & 2 & 2 & 2 & 1 & 11 \\
\hline I & 2 & 2 & 1 & 0 & 1 & 0 & 6 \\
\hline$m$ & 0 & 0 & 0 & 1 & 2 & 0 & 3 \\
\hline$n$ & 2 & 1 & 1 & 2 & 2 & 0 & 8 \\
\hline 0 & 2 & 1 & 2 & 2 & 2 & 1 & 10 \\
\hline$p$ & 2 & 1 & 2 & 1 & 2 & 1 & 9 \\
\hline$q$ & 2 & 2 & 2 & 2 & 2 & 1 & 11 \\
\hline$r$ & 2 & 2 & 2 & 2 & 2 & 1 & 11 \\
\hline s & 2 & 1 & 0 & 2 & 2 & 1 & 8 \\
\hline $\mathbf{t}$ & 2 & 1 & 0 & 0 & 0 & 0 & 3 \\
\hline $\mathbf{u}$ & 2 & 2 & 0 & 0 & 0 & 0 & 4 \\
\hline $\mathbf{v}$ & 0 & 2 & 1 & 2 & 2 & 0 & 7 \\
\hline w & 0 & 2 & 1 & 2 & 2 & 0 & 7 \\
\hline$x$ & 0 & 2 & 1 & 2 & 2 & 0 & 7 \\
\hline Mean & 1.38 & 1.29 & 1.17 & 1.38 & 1.54 & 0.46 & 7.21 \\
\hline Median & 2 & 1 & 1 & 2 & 2 & 0 & 7 \\
\hline Mode & 2 & 2 & 2 & 2 & 2 & 0 & 11 \\
\hline $\begin{array}{l}\text { Standard } \\
\text { deviation }\end{array}$ & 0.19 & 0.15 & 0.18 & 0.77 & 0.78 & 0.51 & 2.83 \\
\hline
\end{tabular}

\section{Key}

0 - Not met

1 - Partially met

2 - Fully met 
Table 4: Study Respondents

\begin{tabular}{|l|l|l|}
\hline Role of hospital based staff & Data collection method & Number interviewed \\
\hline Social worker & Semi-structured interview & $\mathbf{2}$ \\
\hline Safeguarding lead & Semi-structured interview & 3 \\
\hline Paediatrican & Semi-structured interview & 3 \\
\hline $\begin{array}{l}\text { Other health care } \\
\text { professionals }\end{array}$ & Semi-structured interview & 3 \\
\hline $\begin{array}{l}\text { Admin' Staff/Appointment } \\
\text { Bookings }\end{array}$ & Semi-structured interview & 2 \\
\hline
\end{tabular}


Table 5: Codes and categories

\begin{tabular}{|c|c|c|}
\hline Themes & Category & Code \\
\hline \multirow[t]{2}{*}{$\begin{array}{l}\text { DNA Policy and } \\
\text { Terminology }\end{array}$} & Types of DNAs & $\begin{array}{l}\text { Uniqueness of DNAs; "straightforward" and } \\
\text { "difficult DNAs"; knowing the child/family (e.g. } \\
\text { chaotic families); impact of DNA on child }\end{array}$ \\
\hline & Trust policy on DNAs & $\begin{array}{l}\text { Awareness of policy; different interpretations of } \\
\text { policy; barriers to accessing the policy; } \\
\text { promotion of policy }\end{array}$ \\
\hline \multirow[t]{2}{*}{$\begin{array}{l}\text { Reasons for } \\
\text { Non-attendance }\end{array}$} & $\begin{array}{l}\text { Making } \\
\text { appointments }\end{array}$ & $\begin{array}{l}\text { Different systems; inconvenient booking } \\
\text { systems; inflexible systems }\end{array}$ \\
\hline & Reasons for DNA & $\begin{array}{l}\text { Parents forgetting; no longer needing the } \\
\text { appointment; clashes with other appointments; } \\
\text { administrative errors; communication failures; } \\
\text { financial constraints; child care difficulties; time } \\
\text { constraints; and constraints to do with the } \\
\text { hospital system itself }\end{array}$ \\
\hline \multirow[t]{4}{*}{$\begin{array}{l}\text { Response to the } \\
\text { missed apt./child } \\
\text { focussed? }\end{array}$} & Assessing risk & $\begin{array}{l}\text { Seeing a pattern of missed appointments; low } \\
\text { risk medically/high risk safeguarding; "over } \\
\text { attendance and safeguarding (emergency } \\
\text { department)"; flagging child protection } \\
\text { concerns; looked after children; }\end{array}$ \\
\hline & Case notes & $\begin{array}{l}\text { Number of sets of case notes for each } \\
\text { child/young person }\end{array}$ \\
\hline & Who decides & $\begin{array}{l}\text { Role of consultant; responsibility in decision } \\
\text { making; }\end{array}$ \\
\hline & Referrals & $\begin{array}{l}\text { Community vs hospital referrals; } \\
\text { multidisciplinary } \\
\text { team and referrals; referrals for preventative } \\
\text { work/health promotion and safeguarding }\end{array}$ \\
\hline General Practice & Follow-up & $\begin{array}{l}\text { Routine follow-up is often not enough; tracking } \\
\text { across acute and primary care }\end{array}$ \\
\hline
\end{tabular}


"The Corresponding Author has the right to grant on behalf of all authors and does grant on behalf of all authors, an exclusive licence (or non-exclusive for government employees) on a worldwide basis to the BMJ and co-owners or contracting owning societies (where published by the BMJ on their behalf), and its Licensees to permit this article (if accepted) to be published in Archives of Disease in Childhood and any other BMJ products and to exploit all subsidiary rights, as set out in our licence."

Competing Interests None declared.

\section{Funding statement}

'This work was supported by the National Society for the Prevention of Cruelty to Children (NSPCC)'.

\section{Contributorship statement}

JA and CP designed the study. JA and LC sought ethical approval for the study. JA, CP and LC collected and analysed data. All authors contributed to the writing and revisions of this paper. 